\title{
SASKATCHEWAN BREEDING RECORDS FOR RED CROSSBILL, ORCHARD ORIOLE AND RED-HEADED WOODPECKER
}

STANLEY J. SHADICK, Dept. of Physics, University of Saskatchewan, Saskatoon, Saskatchewan, S7N OW0, and BOB LUTERBACH, 631- 65 Westfield Drive, Regina, Saskatchewan, S4S 6A3.

A list of suspected Saskatchewan breeding birds lacking complete documentation has been compiled by Houston, Houston and Gollop'. The purpose of this article is to report new 1980 breeding records for three of these species.

RED CROSSBILL. During the winter of 1979 Red Crossbills were moderately common in Saskatoon. When a few crossbills remained on the university campus in April, it was suspected that they might be breeding. About 16 April Stan Shadick noticed a pair in a row of spruce trees behind the Canada Agriculture Research Station. A nest was located about $5.8 \mathrm{~m}$ above ground in a spruce tree. Although this nest was checked almost daily at noon, it was not until 23 April that the female Red Crossbill was observed sitting on the nest. On 2 May two young crossbills could be seen in the nest. That evening Bob Godwin, Lawrence Baschak and Stan Shadick attempted to photograph the nest but their $3.6 \mathrm{~m}$ ladder was not tall enough. They were able to photograph the adult female when she came to feed the young at approximately one-halfhour intervals. On 5 May there was still at least one young crossbill in the nest. The young were not seen in the nest area when it was checked on 8
May.

ORCHARD ORIOLE. On 30 June Nigel Caulkett and Dale Hjertaas discovered a female Orchard Oriole sitting on a nest $3 \mathrm{~km}$ east of the dam on Buffalo Pound Lake. The nest was made of straw and was located 6-8 m above ground in an elm tree. The male oriole was in first-year plumage. On 12 July Lawrence Baschak and Stan Shadick visited the nest location and found one young oriole out of the nest and at least one bird in the nest. Both birds were being fed frequently by the male but the adult female could not be located.

On 15 and 19 June Vic Harper observed a pair of Orchard Orioles at his farm about $20 \mathrm{~km} \mathrm{NW}$ of Saskatoon. The male was also in firstyear plumage. On 14 July it was apparent that the pair was likely nesting. That evening Chris Escott, Ron Jensen, Lawrence Baschak and Stan Shadick joined Vic Harper in a search for the nest. Eventually it was discovered in the branch of a large spruce tree about $5 \mathrm{~m}$ above ground. The tree was climbed and two young were observed in the nest. On 16 and 18 July the young were being fed away from the nest. We suspect that this site is the most northerly breeding record in North America. 

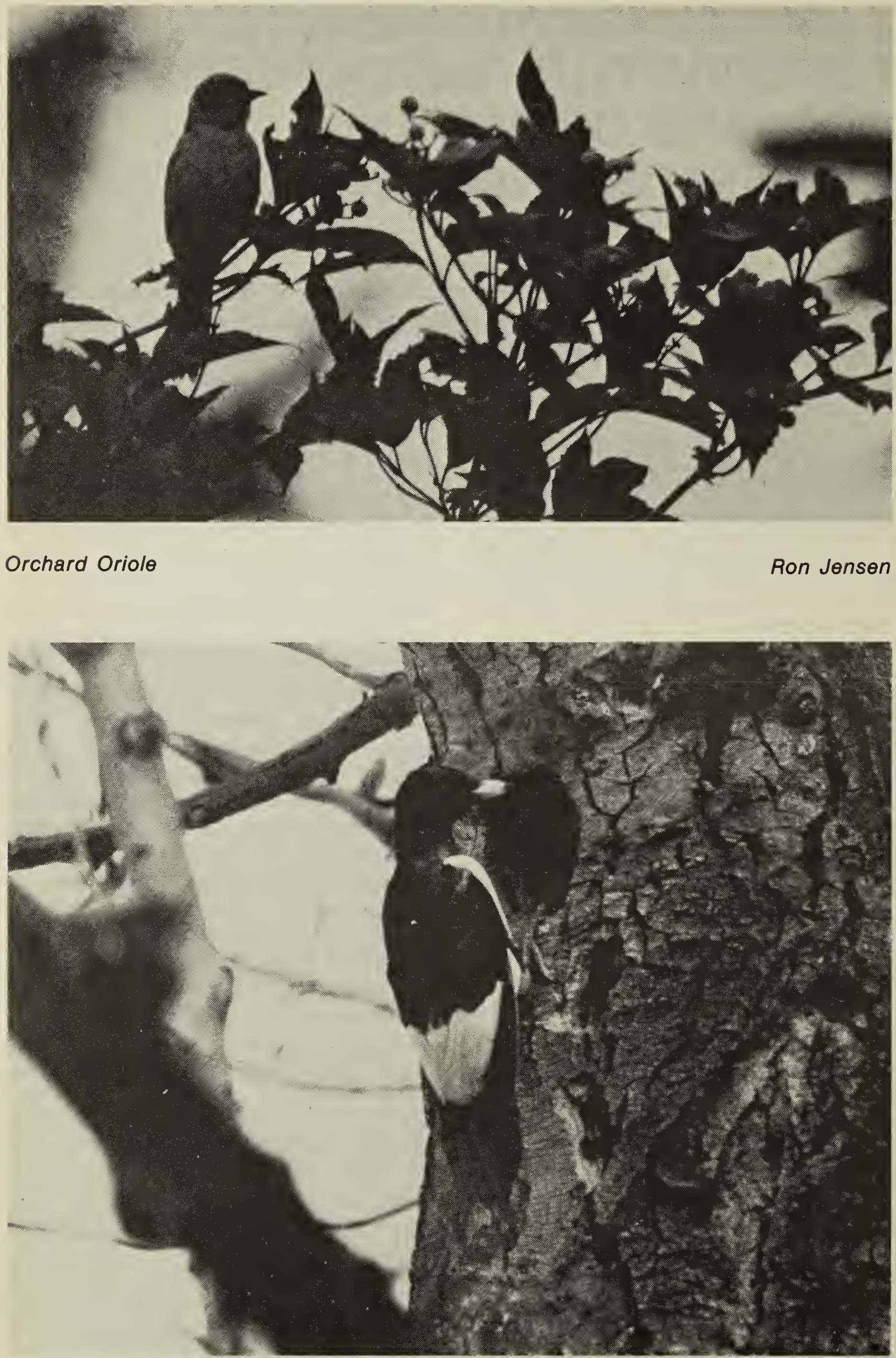
RED-HEADED WOODPECKER. On 5 July Bob Luterbach and Chris Adams observed a pair of Red-headed Woodpeckers at a nest in the Lumsden cemetery. The nest hole was in a dead cottonwood tree. On 12 July Lawrence Baschak and Stan Shadick photographed both adults as they brought food to the nest. This behaviour would indicate that there were young birds inside.

\section{PRINCE ALBERT, SASKATCHEWAN, BIRDHOUSE TRAIL}

KIM HRUSKA and KEVIN ASCHIM, 841 22nd St. East, Prince Albert, Saskatchewan, S6V 1 N9.

This is the third year in which the Prince Albert Birdhouse Trail has been in existence. The trail now consists of 115 houses, stretching south to Rosthern and north to Spruce Home and Meath Park.

As the figures indicate, we had an excellent occupancy rate in our houses but it was unfortunate that we were unable to attract any bluebirds as we did the previous year. We did
On 19 July at 0900 Bob Luterbach arrived at the cemetery to find Stuart Houston searching for the nest tree. The tree had been cut down, and three approximately 15-day-old young were found dead beside the stub. There was no sign of the adults.

'HOUSTON, C. S., M. I. HOUSTON and J. B. GOLLOP. Breeding Birds in Saskatchewan without documented nests. Blue Jay 38:87-95.

have House Wrens and a chipmunk for the first time, however.

There were 10 incidences of another nest being started after the original nestlings left. These nests were probably built by different swallows. Many of the first nestlings left at least a week earlier than those of the past 2 years. This may account for the second nestings.

This nesting season we had little problem with sparrows occupying the bird houses. Sparrow nests were destroyed in three boxes which were later occupied by Tree Swallows. With the destruction of sparrow eggs and young, we hope this success will continue. The sparrows were responsible for the death of six adult swallows; however, four of these were in the same house.

TABLE 1: 1980 Prince Albert Bird House Trail Nestlings.

$\begin{array}{lrlr}\text { Species } & \text { Live } & \text { Dead Young and Eggs } & \text { Houses Used } \\ & & & \\ \text { Tree Swallow } & 547 & 99 \text { (includes 7 adults) } & 105 \\ \text { House Wren } & 12 & 3 & 2 \\ \text { House Sparrow } & & 32 \text { (Destroyed) } & 4 \\ \text { Red Squirrel } & 4 & & 1 \\ \text { Chipmunk (1 Adult) } & & & 1\end{array}$

Natality Rate of Tree Swallows

(Including dead eggs.)

Average Number of Live Young of

Tree Swallows Per House 